\title{
Device or Device Quality Issue
}

National Cancer Institute

\section{Source}

National Cancer Institute. Device or Device Quality Issue. NCI Thesaurus. Code C62948.

A difficulty with the quality of part of the device or the device itself. 